\title{
English and Pictish Terms for Brooch in an 8th-century Irish Law-Text
}

\author{
By COLMÁN ETCHINGHAM and CATHERINE SWIFT
}

\begin{abstract}
THIS paper seeks to draw to the attention of archaeologists, art historians, and others interested in material culture, some hitherto overlooked references to brooches in Old Irish legal texts of the 8th and gth centuries. Of particular interest in these references is the fact that they include Old English and Pictish words for brooches, showing an awareness on the part of the Irish intelligentsia of the elite metalworking of their neighbours in the British Isles. The extent to which this borrowed terminology reflects an appreciation of English and Pictish brooch-types different from the Irish pseudo-penannular of the 8th century is also discussed.
\end{abstract}

Early Irish law-texts contain much information about the material culture of the 7 th and 8th centuries and after. This information deserves to be disseminated more widely, notably among archaeologists and art historians. Fergus Kelly's recent book on early Irish agriculture is an encyclopaedic contribution and will be widely and profitably consulted by those interested in the everyday life and material culture of the Early Middle Ages. ${ }^{1}$ By the interest of archaeologists and others thus awakened, it is to be hoped that greater numbers will be inspired to acquire a grounding in early Irish language sufficient to allow them to explore the legal texts for themselves. This task is undeniably difficult, but by no means impossible, and the reward is enticing. There is much still to be learned and, in the nature of things, the person best-equipped to identify the reality behind a particular phrase or description is an archaeologist or a social historian. Disciplinary collaboration is required if the many early Irish legal texts that are still un-translated or unsatisfactorily translated are not to remain unusable for the foreseeable future by most of those who could make good use of them. The legacy of earlier Irish language scholars, who placed great emphasis on the arcane and incomprehensible nature of the law texts compared with other Irish documentary sources, should no longer discourage those who can now be introduced to their great relevance by the work of Kelly and others.

That some in the past have been discouraged may be suggested by the fact that the evidence of the law-texts finds little or no place in two important and otherwise insightful studies of goldworking (by B. G. Scott) and silver (by J. P.

\footnotetext{
${ }^{1}$ F. Kelly, Early Irish Farming (Dublin, 1997).
} 
Mallory), as reflected in Irish documentary sources. ${ }^{2}$ Scott, to give him his due, made good use of the legal evidence in studying other aspects of early Irish metallurgy. ${ }^{3}$ On the subject of goldworking, however, he remarked that early descriptions of gold and other metals occur mostly in 'literary, religious or historical compositions which have no technological pretensions', revealing 'the often indiscriminate and uncomprehending use of terms'. ${ }^{4}$ Would the legal data, even if comprehensively assembled, methodically translated and exposed to technologically expert scrutiny, merit the same verdict? On the face of it, this seems unlikely. By comparison with sagas, which are, primarily, imaginative compositions, the law-texts' ultimate concern with everyday life gives them greater credence as reflexes of material reality. It is hoped that this paper will prove to be a modest contribution to awareness of what the legal evidence for material culture has to offer.

\section{THE 8TH-GENTURY LAW-TEXT BRETHA NEMED TOÍSECH}

The aim of this paper is to draw attention to a small number of legal passages, hitherto generally overlooked, about an aspect of the material culture of the 8th century that is well known from the artefactual record, namely decorated metalwork brooches. The principal item that concerns us is in the, as yet, largely un-translated Old Irish law-text Bretha Nemed Toisech, 'The First Judgements concerning Privileged Persons'. This lengthy and very difficult text, written in a highly rhetorical style, can be securely dated on grounds of language to the 8th century, and a plausible case has been made that it was written in the reign of Cathal mac Finguine, King of Munster from 72 I to $742 .^{5}$ The text deals with nemed, 'privileged persons', chiefly the literate learned orders of churchmen, scholar-poets and legal experts. Yet the 'book-learning' of these groups is by no means indifferent to the technical skill of craftsmen, upon which Bretha Nemed Toisech touches directly several times. The passage from this law-text that is the focus of our discussion is important for several reasons. Connections long recognised by art-historians between the prestigious metalwork of the Anglo-Saxon, Pictish and Gaelic realms are reflected in a contemporary text. One term for brooch in the relevant passage of Bretha Nemed Toisech is a borrowing from Old English, while another term comes from the largely lost Pictish language, as shown by an explanatory gloss. Glosses on our passage of Bretha Nemed Toisech also show that the operating mechanism of the brooch designated by the Pictish term was considered distinctive. This reflects what we can observe today in the distinctive design and function of surviving 8thcentury Pictish brooches. Moreover, Bretha Nemed Toisech sheds light on the use of metalwork artefacts, including brooches, as items of specific value for accounting

\footnotetext{
${ }^{2}$ B. G. Scott, 'Goldworking terms in early Irish writings', Zeitsch. Celtische Philol., 38 (i 98 I), 242-54 (a reference we owe to Niamh Whitfield); J. P. Mallory, 'Silver in the Ulster cycle of tales', 3 I -78 in D. Ellis Evans et al. (eds.), Proceedings of the Seventh International Congress of Celtic Studies, Oxford, I983 (Oxford, I986).

${ }^{3}$ For example, in B. G. Scott, 'Varia II: I. Early Irish cáer; 2. iarn aithlegtha; 3. crédumae', Ériu, 32 ( I98 I), I53-7; idem, Early Irish Ironworking (Belfast, I 990), I 7 I -2 I 2.

${ }^{4}$ Scott, op. cit. in note $2,25 \mathrm{I}$; cf. his remarks in op. cit. in note 3 (I98I).

${ }^{5}$ L. Breatnach, 'Canon law and secular law in early Ireland: the significance of Bretha Nemed', Peritia, 3 (I984), $439^{-59}$
} 
and exchange purposes. It also raises an interesting question about the broader cultural context in which the 8th-century Irish poetico-learned class were aware of brooch-terminology derived from Pictish and Old English. This study, then, is intended first of all to publicise the relevant texts, with translation, for the benefit of archaeologists and art-historians in particular. Some consideration will also be given to contexts: the textual context, the art-historical context, and the broader historical significance of brooches.

Our passage of Bretha Nemed Toisech occurs in the third part of this law-text, a part that treats of good judicial practice. Many sections of this third part of the text, written in rhetorical, alliterating prose, are addressed to the mythical judge Neire, using the opening formula 'My eloquent Neire, if you be a judge', and concluding with 'my Neire'. Instruction on various aspects of the law are couched in this stylised vein. ${ }^{6}$ In the case of the section that concerns us, the topic is pledges. In early Irish law a pledge was one of the devices by which contracts could be secured. A pledge was an inanimate object deposited as guarantee that a contracted obligation would be fulfilled. Another such device was the human surety or personal guarantor who undertook to ensure that the contract would be completed. ${ }^{7}$ In the section quoted below, exceptionally valuable items (brooches and a drinking vessel) comprise a pledge proper to members of the privileged social elite; specifically, to scholar-poets. The passage runs as follows:

Mo Nere núallgnáith, diamba brithem, bera do nemtiph nadmand glé; gell íar n-ellgibh, oirgell ó féichemnaib frisi n-árgider ollamuin aidilge. Briar derg dleacc [read delg] n-uinge, uinge aile a cataigh caínbláth.

Ballán boise bóighe cúig uinge, ar it é secht n-uinge óir uile ó féichemnuibh frisi n-árgidher ollamuin aidhilgne. Airgille co treise, triangille co seseth, lángille co nómad, nárdílse íar dechmad, mo Nere.

My eloquent Neire, if you be a judge, determine a pure binding surety for privileged persons; a pledge in accordance with poetic compositions, a fore-pledge from litigants, by which ollamain who are found wanting are bound. A red briar is a brooch worth an ounce, another ounce consists of a cataid, fair and smooth [?].

A drinking vessel [?] 'of the palm' [?] is a small vessel worth five ounces, for seven ounces of gold in all are due from litigants, by which ollamain who are found wanting are bound. ${ }^{8} \mathrm{~A}$ forepledge (is payable) up to the third day, a third of the pledge up to the sixth, a full pledge up to the ninth, full forfeiture [?] after ten days, my Nere. ${ }^{9}$

The complete sense of this text, with its technical legal jargon couched in the rhetorical prose style known as $\operatorname{rosc}(a d)$, is not easily recovered. The key point, however, is that a competent judge should ensure that privileged persons (nemed),

\footnotetext{
${ }^{6}$ Breatnach, op. cit. in note $5,444^{-} 5$.

7 For a convenient summary of the legal principles see F. Kelly, A Guide to Early Irish Law (Dublin, I 988), I64-76.

8 The phrase, found in both paragraphs, frisi n-árgid(h)er ollamuin aid $(h) i l g(n) e$, we translate on the basis of reading, literally, 'ollamain of necessity', or the like; one might, alternatively, read ollaman, preposed genitive singular, and translate in both cases 'by which what is needed of an ollam is bound'.

${ }^{9}$ The text is diplomatic, from D. A. Binchy (ed.), Corpus Iuris Hibernici, 6 vols. (Dublin, I 978), vi, 2223. I 8-23, but with length-marks and punctuation (where necessary) supplied. The concluding statement about the step-by-step forfeiture of the pledge is separately cited and glossed ibid., vi, 2004.3-7. We have not ventured to suggest a linedivision on the basis of the pattern of linking and internal alliteration between and within semantic units. This working translation, tentative in some respects, is our own. Bretha Nemed Toisech was read in seminars at Trinity College Dublin, in the I 980 s and I 990 , conducted by Liam Breatnach, who is currently working on a complete edition, having previously published the first part as 'The first third of Bretha Nemed Toisech', Eriu, 40 ( I 989), I-40.
} 
exemplified here by ollamain (plural), will lodge pledges of a value consistent with their high status. While an ollam (singular), literally a 'supreme one', may be a master of any profession, or even a king, ${ }^{10}$ the term usually refers to a master-fili. The latter word is generally translated 'poet', but actually means an expert in a wide range of Gaelic-language learning and literature, both prose and poetic. Here this high-status, literate, learned person is obliged to give a pledge 'in accordance with poetic compositions' (iar n-ellgibh). The word ellach denotes a poetic composition or metre, so the allusion is to poetic skill, which is among the qualifications of a master-fili, and which is expected to fix the scale of pledge required of him. ${ }^{11}$ The pledge proper to a master-fili is envisaged as comprising two brooches (the briar and cataid of the first paragraph quoted), plus a small drinking vessel (the bóige defined in the second paragraph). The fore-pledge, mentioned in both paragraphs, is an advance payment signifying an intention to lodge the full pledge, something that is envisaged as being done in instalments over nine days.

Use of a bóige, 'small drinking vessel', as a pledge appropriate to the master-fili is confirmed by Cormac's Glossary. This glossary of difficult words is traditionally ascribed to Cormac mac Cuilennáin (†9o8), King and Bishop of Munster, and its core can certainly be dated no later than his era. ${ }^{12}$ Cormac's Glossary offers explanations of a number of words from Bretha Nemed Toisech. Citing the above passage and commenting on the word bóige for a vessel, Cormac observes:

nobíd dano fri geall d'filedaib 7 d'ollamnaib

moreover, it was wont to serve as a pledge for filid and ollamain. ${ }^{13}$

So much for the general import of the passage in Bretha Nemed Toisech; let us now focus on the references to brooches. We can shed no useful light in the present context on the drinking vessel: its exceptional value (five ounces of gold) raises the problem of its material composition, whether of precious metal or, perhaps, of glass ${ }^{14}$ but an investigation of the Early Irish terminology for drinking vessels and possible reflexes in the artefactual record, while most desirable, is impossible within the parameters of a study of these dimensions. ${ }^{15}$ Our concern in this paper is limited to the words for brooch in Bretha Nemed Toisech.

THE OLD ENGLISH LOAN-WORD FOR A BROOGH

Of the two key words, the first is briar. It is a borrowing of Old English brer (later 'brier', 'briar') into Old Irish and is explained in several medieval Irish

${ }^{10}$ See G. Etchingham, Church Organisation in Ireland AD 650 to Iooo (Maynooth, I 999), I $63-4$.

11 Breatnach, Uraicecht na riar (Dublin, I987), presents a detailed study of the status of the fili.

12 P. Russell, 'The sounds of a silence: the growth of Cormac's Glossary', Cambridge Medieval Celtic Stud., I 5 ( I 988 ), I-30; idem, 'Dúil Dromma Cetta and Cormac's Glossary', Études Celtiques, 32 ( I 996), I 47-74.

${ }^{13}$ K. Meyer (ed.), Sanas Cormaic: An Old Irish Glossary compiled by Cormac úa Cuilennáin, Anecdota IV (ed. Bergin et al., Halle, i 9 I 2 ; repr. Felin Fach, I 994), I 4 \& I 42.

${ }_{14}$ We are grateful for Niamh Whitfield's comments on this matter.

${ }^{15}$ We can say, however, that Cormac's Glossary also specified that a bóige was a type of small ballán, the latter an acorn-shaped drinking vessel which could be made of wood; Meyer, op. cit. in note i $3, \$ \S$ i 42 and i67. See G. Swift, 'Old Irish for archaeologists - an interdisciplinary perspective', in M. Meek and M. Crozier (eds.), Festschrift for Ann Hamlin (forthcoming). 


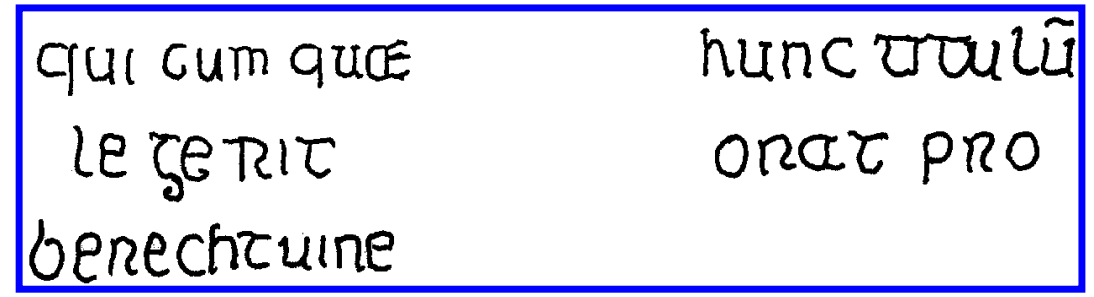

FIG. I

The dedication to the Englishman Berechtuine on the slab at Tullylease, Co. Cork.

glossaries as a pin or brooch. ${ }^{16}$ The Old English/Middle English word is not attested in this sense, however, but only in that of a 'briar, thornbush, thorn, wild rose'. It is possible that the Irish glossators interpreted the loan-word briar simply as a direct parallel to the Irish word delg, a word that can mean both a thorn and a pin and, by extension, a brooch. Alternatively, could the meaning attached to the loanword in Old Irish reveal a wider semantic range for the original Old English term and one that is no longer recoverable from surviving English texts? In other words, might Old English brer itself have borne the connotation 'brooch' for English speakers? There is apparently no evidence that would support such a hypothesis. ${ }^{17}$ For the present, we can only suggest that Irish scholars indulged in clever wordplay here, adopting an Old English word they knew partly paralleled delg in meaning to allude to a brooch that may have been of distinctively Anglo-Saxon type. It is to be noted that the passage quoted above from Bretha Nemed Toisech is the only instance so far recognised of briar as a 'real' loan-word into Old Irish vocabulary, and not just a glossary item.

Use of an English loan-word to refer to a brooch in an Old Irish text of the 8th century is, in itself, highly significant. It is a striking, contemporary, documentary reflex of relations between the two cultures in the sphere of decorative metalworking, a relationship that is, in a general sense, suggested by the metalwork artefacts themselves. The terminological borrowing was perhaps prompted by a need to designate distinctive brooch-types identified respectively with Ireland and England. It is a striking coincidence (if coincidence it be) that medieval traditions about the composition of the law-text Bretha Nemed Toisech were transmitted at Tullylease, Co. Cork, for this site is sometimes known as Tulach Léis na Sacsan (Tullylease of the English). ${ }^{18}$ A tangible witness to its Anglo-Saxon associations is the finely carved cross-slab commemorating Berechtuine, the common Old English male name Beorhtwine (Fig. I). A recent study tentatively proposes an 8th-century date for the slab, both on art historical grounds and on the basis of the spelling of the name, which apparently reflects the spelling conventions of 8th- and 9thcentury manuscripts from outside Wessex. ${ }^{19}$

${ }^{16}$ See the Royal Irish Academy Dictionary of the Irish Language [henceforward RIA Dictionary] (Dublin, I913-76), 'B', I $85.16-2$ I.

${ }_{17}$ For comment on the meaning of brêr we are indebted to Ian McDougall of the Dictionary of Old English project at the University of Toronto.

${ }^{18}$ Breatnach, op. cit. in note 5, 44 I; E. Hogan, Onomasticon Goedelicum (Dublin, r 9 ro; repr. ibid. r 993), 656.

${ }^{19}$ I. Henderson and E. Okasha, 'The early Christian inscribed and carved stones of Tullylease, Co. Cork', Cambridge Medieval Celtic Stud., 24 (1992), I-36 at pp. 8-12, I $5^{-1} 7$ and $22-4$. 
It is reasonable to suppose that the 'red briar', mentioned as an example of a brooch worth an ounce, is a specific kind of artefact, perhaps one of distinctively Anglo-Saxon type. As regards the red colour of the briar, perhaps the imagery of the thorn (bush) is continued. In terms of the actual appearance of the brooch, however, we might envisage red enamel or, perhaps, in the case of an Anglo-Saxon brooch, glass or garnet. Alternatively, the reference could be to dergór, 'red gold', a term found elsewhere in Irish legal and literary material. ${ }^{20}$ It is noteworthy that Cormac's Glossary, quoting our passage of Bretha Nemed Toisech, explains briar as delg unga óir, 'a brooch worth an ounce of gold'. ${ }^{21}$ Indeed, Bretha Nemed Toisech itself indicates an ounce of gold, specifically, as the value of the briar: the second paragraph quoted above states that the whole pledge proper to an ollam comprised seven ounces of gold, of which the drinking vessel is valued at five ounces. Each of the two brooches mentioned in the first paragraph is, accordingly, valued at one ounce of gold. Of course, that each brooch was worth an ounce of gold is not necessarily any indication of the actual metal content of the brooches themselves.

The redness of the briar is the subject of comment in what is known as O'Davoren's Glossary. This important text was a product of the later medieval Gaelic legal tradition, but is invaluable in its citation of much earlier material. Admittedly, one can be absolutely confident about the antiquity of any particular glossary item in such a collection only when it is also found in an indisputably early context, such as Cormac's Glossary. Nevertheless, we should not be hyper-sceptical about resorting to a text such as O'Davoren to cast light on Early-medieval usage: this is not a literary narrative that might be remodelled or even composed afresh in accordance with the author's particular agenda. The operating conventions of medieval glossaries and especially legal glossaries were different. Free surmise was not usual; rather, it was normal to draw on the established corpus of scholarship, so that individual glosses or elements thereof are constantly repeated and are often demonstrably of Early-medieval origin. ${ }^{22}$

Thus one should not lightly disregard O'Davoren's Glossary when it quotes our passage from Bretha Nemed Toisech and remarks of the briar that it is derg fria bruith. This may be rendered 'red with respect to its melting/refining/heating [?]'. ${ }^{23}$ Does this refer to a brooch manufactured from dergór 'red gold'? Dergór is conceivably the product of alloying gold with copper to produce a red hue, as suggested by Scott. Mallory is surely justified, however, in his objection that an

\footnotetext{
${ }^{20}$ The possibility of a reference to dergór was suggested to us by Niamh Whitfield; see Kelly, op. cit. in note I, 594; J. Vendryes, 'Notes critiques sur des textes: 5', Etudes Celtiques, 4 ( 1948), $3^{\text {I }} 3^{- \text {I }}$; Scott, op. cit. in note 2, 243 and $246-7$ n. I 3 ; Mallory, op. cit. in note $2,36-7$.

${ }^{21}$ Following Kelly's translation (op. cit. in note 7, I I4) of a comparable usage, rather than 'a brooch of gold weighing an ounce'; Meyer, op. cit. in note I 3, I $4 \S$ I 43 .

${ }^{22}$ For the value of O'Davoren's glossary see, for example, the remarks of Kelly, op. cit. in note 7, 25 I-2, 257-9, 262, 269 (no. I6), 273 (no. 38), 275 (no. 48) and 276 (no. 52), and also Breatnach, 'On the original extent of the Senchas Már', Ériu, 47 (I 996), I-43 at pp. Io-I4 and 28-37; on legal glossing in general see conveniently the remarks of Breatnach, 'Law', ro7-2 I in K. R. McCone and K. Simms (eds.), Progress in Medieval Irish Studies (Maynooth, I 996), at pp. I I 4- I $5 \$ 5.2$ and I I $\$ 6.5$, and the other literature there cited; see Russell (I988), op. cit. in note I 2, 28; idem ( 1996 ), op. cit. in note 12 , passim.

${ }^{23}$ Binchy, op. cit. in note 9, I 473.36 ; W. Stokes, 'O'Davoren's Glossary', 229-30 in W. Stokes and K. Meyer (eds.), Archiv für Celtische Lexicographie, 2 (Halle, I 904), 229-30 \$ 200, where the editor despaired of elucidating the entry; on the meaning of bruth see M. A. O'Brien, 'Varia IV', Ériu, I I (I932), I 54-7 I at p. I 70; Scott, op. cit. in note 2,246 n. I 3 .
} 
alloy of gold with a base metal sorts ill with the fact that dergór was esteemed as a substance of the highest value. ${ }^{24}$ Accordingly, perhaps there is something to be said for an alternative canvassed by Scott. Dergór could signify a de-silvering process, in which the gold was kept at a red heat, insufficient to melt it but adequate for separating out any silver. This would tend to enhance the reddishness of the gold thus purified. ${ }^{25}$ In that event, the derg in dergór could denote the red heat of the process, the reddishness of its product, or both. However that may be, we cannot be sure that the brooch called briar, defined by O'Davoren's Glossary as derg fria bruith, was, in fact, an artefact manufactured from dergór. Apart from anything else, brooches surviving from the Early Middle Ages and made entirely from gold are apparently unusual, as we shall see. Nevertheless, the connotations of 'heat' and 'fiery glow' borne by the word bruth indicate that O'Davoren's Glossary refers to a metallurgical feature. The word bruth does not seem to be attested in a looser sense, such as might indicate simply that the brooch had a brilliantly red appearance. ${ }^{26}$

Another legal glossary, Dúil Dromma Cetta, which also seems to have originated in the Old Irish period (i.e. before the Ioth century), ${ }^{27}$ includes the following article:

Briar: delg co tócbáil fora cinn .i. brí tulach.

For tócbáil, the key word here, Charles Plummer suggested 'handle'; generally, however, tócbáil refers to the act of raising, and so may denote something raised on the 'head' (fora chiunn) of the brooch. Since, as we shall see, cenn seems elsewhere to be used of the ring, hoop or head of a brooch (as contrasted with cos, 'foot', denoting the pin), something protuberant would seem to be intended. In that event, this comment on briar might be translated 'a brooch with an elevation on its head/ring, that is, a "hill of mounds"'. Here bri, 'hill', is a partial etymological gloss on briar, that is, an attempt to explain the word by breaking it down into its supposed constituents. At the same time bri seemingly plays on the image of the cenn, 'head', of the brooch as a 'hill', which is itself topped by 'mound'-like protuberances or bosses (tulaig). ${ }^{28}$ The occurrence of bosses in itself can hardly have been thought characteristic of a brooch-type designated by an Old English loan-word, given that bosses are also found on 'Irish'-type pseudo-penannular brooches of this era, such as the Tara or Hunterston brooches. Might the briar rather denote the distinctive and quite splendid Anglo-Saxon type of composite disc-brooch of the 7 th (and early 8th?) centuries, such as the Sarre, Kingston Down and Boss Hall brooches (Figs. 2 and $3 \mathrm{~d}$ )? The prominent disc-shaped head (= cenn?) of such a brooch was itself surmounted by protuberant bosses, one large boss at the centre surrounded by four satellite bosses. Is this what is referred to by the expression bri tulach? If we ignore O'Davoren's apparent indication that the 'redness' of the briar stems from some metallurgical process, this feature might be

\footnotetext{
${ }^{24}$ Scott, op. cit. in note 2, 243; Mallory, op. cit. in note 2, 36-7.

${ }^{25}$ Scott, op. cit. in note $2,246-7$ n. I 3 .

${ }^{26}$ RIA Dictionary, 'B', 2 I 6- I 7.

${ }^{27}$ Russell ( 1996), op. cit. in note I 2, esp. I65.

${ }^{28}$ Binchy, op. cit. in note 9, 6o6.33; cf. RIA Dictionary 'B', I 84. I I-39, for brí ibid., 'T', 20 I.26-8, for tócbáil; ibid., 376-8, for tulach, 'hill(ock), mound', which we read here as genitive plural.
} 


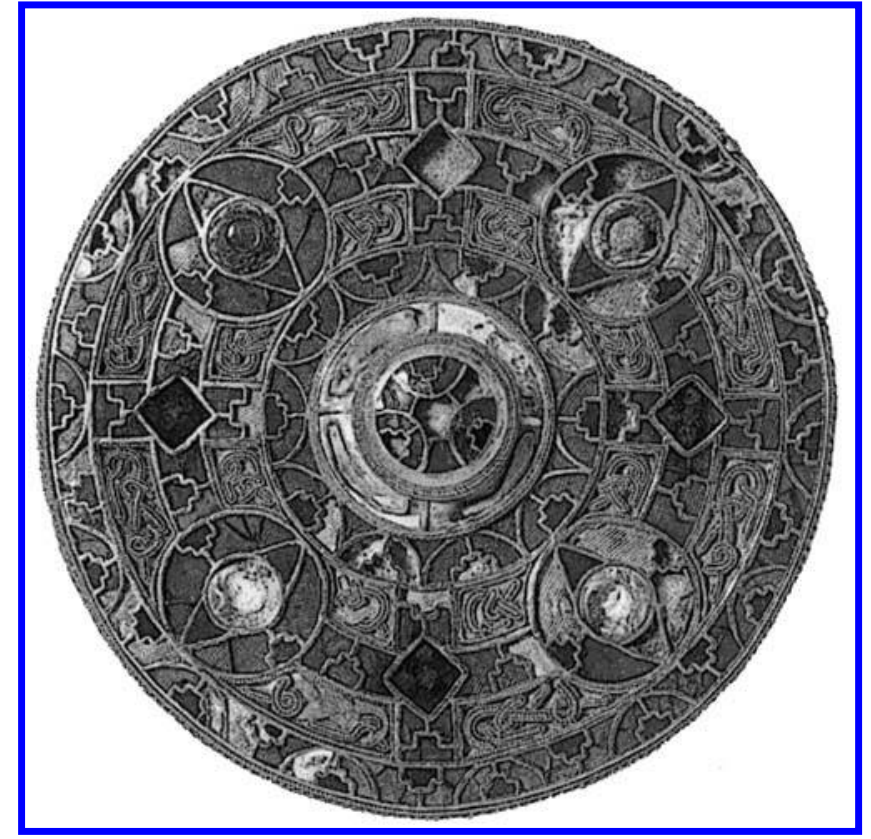

FIG. 2

The Anglo-Saxon composite disc brooch from Kingston Down, Kent.

accounted for, alternatively, by the lavish use of garnet in decorating these AngloSaxon composite disc-brooches. ${ }^{29}$ While acknowledging the difficulties posed by O'Davoren's phrase, therefore, the present writers tentatively propose the composite disc-brooch as a candidate for identification with the distinctive, high-value brooch, designated by the Old English loan-word briar in an 8th-century Irish lawtext.

\section{THE PICTISH WORD FOR BROOCH}

The second unusual term for a brooch found in our passage of Bretha Nemed Toisech is there spelled cataigh; it too is said to be worth an ounce, again, seemingly, an ounce of gold. This word also appears in Cormac's Glossary (though, in this case, without specific indication that Bretha Nemed Toisech is the source) as follows:

Catit nó Cartait .i. delg .i. bérla Cruithnech .i. delg ara-cuirit[h]er a chos

Catit or Cartait, i.e. a brooch, i.e. in the Pictish language, i.e. a brooch the pin [cos, literally, 'foot'] of which turns back/turns away [?]. ${ }^{30}$

The forms catit/cartait in Cormac's Glossary are doubtless to be preferred; the final -gh in Bretha Nemed Toisech (cataigh) is merely a scribal substitution of a type that is common in the British Library Nero A 7 manuscript. ${ }^{31}$ The basic meaning of the

\footnotetext{
${ }^{29}$ See e.g. L. Webster and J. Backhouse (eds.), The Making of England: Anglo-Saxon Art and Culture AD 6oo-9oo (London, I99 I), 48-53, nos. 3I(a), 32(a) and 33(a); we owe this reference to Niamh Whitfield.

${ }^{30}$ Meyer, op. cit. in note I 3,25 \& $30 \mathrm{I}$; for cos, 'foot', in the meaning 'pin of a brooch', see RIA Dictionary 'C', $488.78 \mathrm{ff}$, citing sreth . . . di bretnasaib ...7 a cosa isind fraigid, 'a row of brooches with their pins in the wall'.

${ }^{31}$ See Breatnach, op. cit. in note 9,3 .
} 
verb ar-cuirither is given as 'increases, extends, prolongs', but Cormac is hardly to be read here as merely stating the obvious, namely, that the pin 'extends' the brooch. One would expect, rather, an allusion to a specific characteristic of this type of brooch. 'Turns back, turns away', tentatively proposed as a subsidiary meaning by the compilers of the Dictionary of the Irish Language, ${ }^{32}$ seems appropriate, as we shall see presently. The key point is that catit/cartait is identified by Cormac's Glossary as a Pictish word for a brooch. Kenneth Jackson's verdict was that it is 'certainly neither Gaelic nor Welsh'. ${ }^{3}$

Not surprisingly, the vast bulk of the terms Cormac's Glossary set out to explain around A.D. goo are Gaelic. Knowledge of Latin is displayed, as one would expect, and also of Greek and, to some extent, of Hebrew. Old Welsh/British is the second most commonly noticed Insular language. Cormac shows awareness of Old English and of Old Norse, the latter a most intriguing feature in a work of clerical scholarship from as early as about A.D. 90o. ${ }^{34}$ The article quoted above, however, is the only instance of a Pictish word expressly identified as such in Cormac's Glossary and is, therefore, an item to be treasured no less than the artefact it denotes, given that Pictish is, for the most part, a lost language. It is interesting that Cormac's Glossary suggests at least some knowledge of this language among Irish scholars at about the period when Pictland was being assimilated in the emerging kingdom of Scotland.

The explanation of catit/cartait in Cormac's Glossary has been partly publicised by philologists who, however, have confined themselves to remarking on the identification of the word as Pictish. One such commentator, John Fraser, was confident in 1927 that 'from catit (or, cartit) we can learn nothing about the Picts'. ${ }^{35}$ Happily this is not the case, although others have also made remarkably little of the reference. Art history, a discipline that, to the best of our knowledge, has not been confronted previously with this textual evidence, may shed light on the meaning of catit/ cartait.

To be fair to earlier commentators, the magnificent hoard of silverware from St Ninian's Isle, Shetland, came to light only in I $95^{8}$. Its brooches, together with that from Aldclune, Blair Atholl, revealed in I980, as well as other modern discoveries, expand substantially the extant corpus of decorated brooches of a type characterised as Pictish. Indeed, an extended study of Pictish brooches was not available until David Wilson's catalogue of, and commentary on, the St Ninian's

\footnotetext{
${ }^{32}$ RIA Dictionary 'A', $385 \cdot 42-7$.

${ }^{33}$ K. H. Jackson, 'The Pictish language', s 29-66 in F. T. Wainwright (ed.), The Problem of the Picts (Edinburgh, I955), I34; an earlier suggestion (W. Stokes, 'On the linguistic value of the Irish annals', Trans. Philol. Soc. (I888-9o), 365-433 at p. 397) that it is 'borrowed from AS. geard or Welsh garthon 'goad', Corn. garthou (gl. stimulus)', has not found favour; Roibeard O Maolalaigh has drawn our attention to the term cotut 'hard', denoting delenition in the Irish Grammatical Tracts, but there is no obvious connection with the Pictish word for a brooch.

${ }^{34}$ Cormac's use of Norse was noted by C. Marstrander, Bidrag til det Norske Sprogs Historie i Irland (Kristiania, I 9 I 5), 93), and in passing by Russell ( I 988 ), op. cit. in note I 2, 20.

${ }_{35}$ J. Fraser, 'The question of the Picts', Scottish Gaelic Stud., 2 ( I 927), I $72-20$ I at p. I 85; cf. Stokes, op. cit. in note 33, 397; T. F. O'Rahilly, Early Irish History and Mythology (Dublin, I 946), 355n, for an indirect reference; Jackson, op. cit. in note 33, I 34; K. Forsyth, Language in Pictland (Utrecht, I 997), 28n (but Russell ( I988), op. cit. in note I 2 , to whom she refers, in fact makes no mention of the Pictish word in Cormac's Glossary).
} 
Isle treasure was published in $1973 \cdot{ }^{36}$ Pictish art, in metal as much as the stonecarving that has long been appreciated, speaks eloquently of the sophistication of an Early-medieval Insular culture of which we have almost nothing in its own words. In that context, it is an extraordinary stroke of good fortune that an Irish law-text of the 8th century should contain, in catit/cartait, a Pictish word for brooch. Even more remarkable is the fact that Cormac's Glossary, compiled perhaps I 50 years after the composition of Bretha Nemed Toisech, appears to refer to the distinctive design that can be recognised in the surviving examples of brooches emanating from Pictland in and after the 8th century.

It is commonly maintained that, in Ireland, after the 7 th century, the zoomorphic penannular brooch was largely replaced by a type that is annular or pseudo-penannular, that is to say, the terminals of the ring or hoop are joined by a bar or panel. They are, in effect, 'pseudo-terminals'. Unlike these Irish counterparts, Pictish brooches of the 8th century remained truly penannular, with a gap between the terminals of the ring or hoop, through which the pin could be passed and by means of which the ring/hoop could then be turned past the pin to secure the brooch: Cormac's use of the verb ar-cuirether, if in the sense 'turns back, turns away', might refer to passing the pin between the terminals of the ring/hoop. The technique for affixing to a garment a Pictish catit/ cartait was quite different from that employed with an Irish pseudo-penannular brooch (such as the Tara Brooch), in which the purely decorative ring/hoop had no fastening function (Fig. 3a). ${ }^{37}$

Of course, one should not overstate the independence of Irish and Pictish brooches in the 8th century for, as has been remarked, they 'did not develop in isolation from one another, and hybrid examples which contain elements of both traditions are known'. Such examples include the brooch from Ervey, Co. Meath, and one of the St Ninian's Isle brooches. Moreover, Niamh Whitfield suggests to us that the true penannular brooch may not have died out altogether in Ireland in the 8th century. ${ }^{38}$ Granted these caveats, the general pattern is evidently of a functional and regional distinction. It is emphasised by the fact that some Irishtype pseudo-penannular brooches were apparently modified in Pictland to remove the bar or panel joining the terminals, so making them truly penannular. (There are three examples of these modified brooches in the 'Work of Angels' catalogue.) $)^{39}$

There is an apparent difficulty, however, about taking the expression aracuirether a chos, 'the pin of which turns back/away', in Cormac's Glossary as a reference to the method of fastening a Pictish penannular brooch. In securing such a brooch, the most obvious turning action is not that of the pin; rather, it is the ring or hoop (cenn) of the brooch that 'turns' past the pin (cos). Accordingly, if Cormac intended to refer to the method of fastening the brooch, one might have expected him to describe it as delg ara-cuirither a chenn, 'a brooch the head of which turns

\footnotetext{
${ }^{36}$ D. M. Wilson, 'The treasure', 45-148 in A. Small, G. Thomas and D. M. Wilson (eds.), St Ninian's Isle and its Treasure (Oxford, I 973), esp. 67-I05; R. Ó Floinn, 'Secular metalwork in the eighth and ninth centuries', 72-I 24 in S. Youngs (ed.), The Work of Angels (London, I 989), , o8- I6; cf. ibid. I 55-6.

${ }^{37}$ See Wilson, op. cit. in note $36,8 \mathrm{I}-8,98$, I 03 ; Ó Floinn, op. cit. in note 36, esp. 89-9o.

38 Ó Floinn, op. cit. in note 36,$90 ;$ N. Whitfield, pers. comm.

${ }^{39}$ Wilson, op. cit. in note $36,83-5,87$ and 98 ; Youngs, op. cit. in note 36,90 (no. I95), 94 (no. 72), 96-7 (no. 75) and 200 (no. I95).
} 


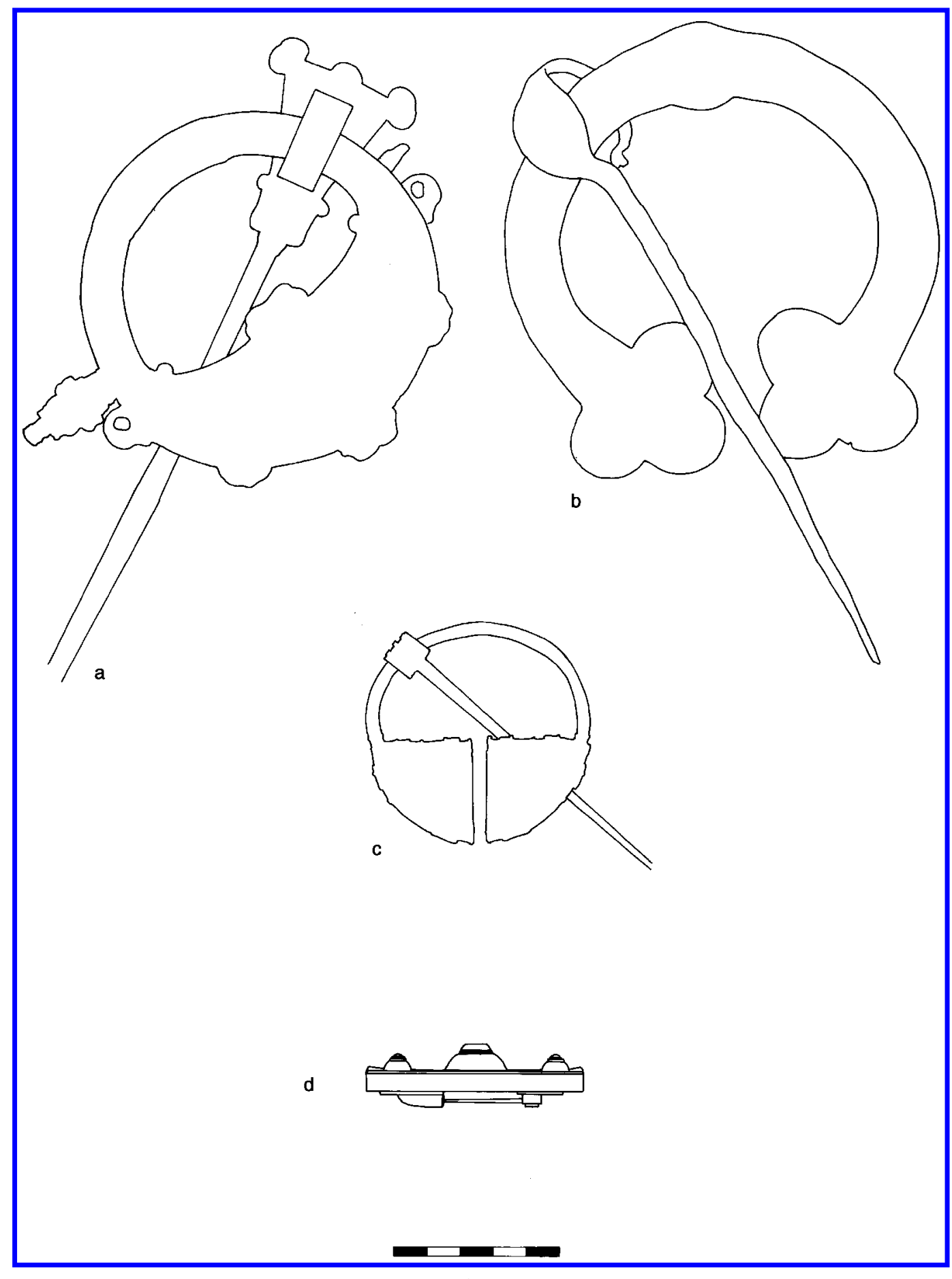

FIG. 3

Diagrammatic representation of relevant brooch-forms. (a) Irish pseudo-penannular brooch of the 'Tara' type; (b) Pictish penannular brooch of the Rogart type; (c) Irish bossed penannular brooch; (d) profile of AngloSaxon composite disc brooch. Based upon real examples and drawn to scale (here r:2). 
back/away'. Cormac's definition of the Pictish catit/cartait as a delg ara-cuirither a chos, 'brooch the pin of which turns back/way', more likely describes the distinctive design-feature of the artefact itself, without reference to its fastening method: i.e. the fact that the pin can pass between the terminals of the ring or hoop. Alternatively, as suggested to us by Niamh Whitfield, Cormac may refer to the distinctive way in which the pin of a Pictish brooch is affixed to the ring or hoop. Pictish brooches lack the elaborate pin-heads of Irish brooches: instead, the top of the pin is hammered flat and turned back over the ring/hoop, among other things facilitating easy removal of the pin. The Old Irish verb ar-cuirither might then denote the 'turning back' of the head of the pin over the ring/hoop or, even, perhaps, 'turning away' in the sense of the pin's detachability. In any event, there is good reason to consider that some aspect of the distinctive design of a Pictish penannular brooch, as observable in extant examples, is remarked upon in Cormac's Glossary (Fig. 3 b). ${ }^{40}$

As we have seen, O'Davoren's Glossary discusses the Old English loan-word for a brooch, briar, in an entry that quotes our passage of Bretha Nemed Toisech. O'Davoren's Glossary also quotes, from our passage of Bretha Nemed Toisech, the expression cataid caoinblath which may be translated 'a catit/cartait, fair and smooth'. This citation of Bretha Nemed Toisech is fuller than that of Cormac, in that it includes the qualifying adjectives cainblath, together with the Pictish loan-word itself. O'Davoren differs further from Cormac, in that the Pictish derivation of catit/ cartait is not expressly mentioned. Instead, O'Davoren offers an etymology, expressed in Latin and seemingly garbled in transmission, which evidently treats catit/cartait as if it contained the Irish element (do)tuit, 'falls': cutendo $n$ - accepit, perhaps to be emended to a cadendo nomen accepit 'it received its name from falling', as suggested by D. A. Binchy. ${ }^{41}$ Obviously this cannot be a true etymology, if we follow Cormac's Glossary in taking this to be a Pictish word. A tendency in the past to disregard such medieval speculations as worthless 'pseudo-etymologising' has, however, given way recently to greater understanding of medieval glossing and what it may reveal. ${ }^{42}$ Accordingly, O'Davoren's comments are perhaps to be considered a medieval reflection on the form or function of the brooch-type designated a catit/cartait, rather than an explanation that is incompatible with that adopted by Cormac. O'Davoren elaborates:

dealg co nduillinn inn sin, 7 dotuit ara ceanntruime in tan doroltar a cos ara cenn

that is a brooch with a leaf, and it falls on account of its top heaviness, when its pin is turned over [?] its ring/hoop.

Duillend, literally 'a leaf', can refer, by extension, to the leaf-shaped blade of a spear, and thus to a spear. Whitley Stokes, in editing O'Davoren's Glossary a hundred years ago, read the article in this sense and was followed by the compilers

${ }^{40}$ See e.g. Youngs, op. cit. in note 36,90 , and, for a good illustration of the pin-head of a Pictish brooch, Small et al. (eds.), op. cit. in note 36 , pl. XXXVI (Rogart); Whitfield, pers. comm.; we thank Dan McCarthy for comments on the mechanism of the brooch.

${ }^{41}$ Binchy, op. cit. in note 9, I 473.37-8; Stokes, op. cit. in note 23, 229-30 § 200; for comment on cainblath, we are indebted to Caoimhín Breatnach.

${ }^{42}$ See Breatnach, op. cit. in note 22 , I I $4^{- \text {I }} 5 \S 5.2$ and I I $9 \S 6.5$ and literature there cited. 
of the Dictionary. ${ }^{43}$ Presumably they equated duillend with a 'spear-like' pin, but O'Davoren or his source(s) hardly thought it worthy of remark that the broochtype called catit/cartait had a pin. Could duillend refer metaphorically to some other leaf-like feature of the brooch, as it is taken to do in the expression duillend-delg oir, 'leaf-brooch of gold', in Táin Bó Cúailgne? Cecile O'Rahilly translated this as 'leafshaped brooch of gold' and was followed by Mallory who, accordingly, suggested a kite brooch. This would seem to pre-judge and perhaps one should follow Kelly's more cautious 'leaf-brooch of gold', which allows that a component, rather than the general appearance of the artefact as a whole, prompted comparison with a leaf. ${ }^{44}$ Since the duillend of O'Davoren's Glossary is a feature of the catit/cartait, otherwise identifed as Pictish and dated by its occurrence in Bretha Nemed Toisech to no later than the 8th century, a reference here to a Viking-age kite brooch would only be admissible if O'Davoren's Glossary could be shown to be re-interpreting an earlier explanation in the light of later artefacts.

The verbal form doroltar is also problematic, but clearly describes some aspect of the movement of the cos 'foot' (pin) in relation to the cenn 'head' (ring/hoop) of the brooch. ${ }^{45}$ Whatever its precise significance may be, O'Davoren's Glossary, like the independent treatment of the catit/cartait by Cormac, would appear to present as distinctive the relationship of the pin to the ring/hoop, in terms either of the fastening technique, the motion of the pin, or of the mechanism by which the pin was attached to the ring/hoop. O'Davoren's comments in both Latin and Irish, therefore, focus on the brooch's tendency to 'fall' and his remarks in Irish attribute this to its 'top heaviness' (cenntruime), the ring/hoop (cenn) being characteristically heavy, perhaps when it pivots in relation to the pin. In principle, of course, an Irish-type pseudo-penannular, just as well as a Pictish-type penannular, could be seen as characteristically 'top heavy' in this sense. Niamh Whitfield suggests to us another possibility, namely, that the gloss may allude to the general practice of wearing brooches with the pin pointing upwards away from the body.

We should expect, however, that O'Davoren's Glossary, like Cormac's, attempted to define the catit/cartait by reference to some feature(s) peculiar to this brooch-type. Is its 'top heaviness' connected with this brooch's having a duillend, 'leaf'? One might be tempted to speculate that duilend denotes the expanded terminal of a penannular brooch of Pictish type, which has been described as 'lobed or trefoil' (cf. Fig. 3 b). ${ }^{46}$ Since the brooch has two terminals, however, one might in that case anticipate a reference to delg co nduillendaib, 'a brooch with leaves', rather than the singular form co nduillinn. Accordingly, for the present we can offer no satisfactory explanation of the reference to a leaf in O'Davoren's

\footnotetext{
43 Binchy, op. cit. in note 9, I 473.37-8; Stokes, op. cit. in note 23, 229-30 § 200; RIA Dictionary, 'D', 439.33-6I. ${ }^{4}$ C. O'Rahilly, Táin Bó Cúailgne Recension I (Dublin, I976), 79.2598, i96; J. P. Mallory, 'The world of Cú Chulainn: the archaeology of Táin Bó Cúailgne’, I 03-59 in idem (ed.), Aspects of the Táin (Belfast, I 992), I 45; Kelly, op. cit. in note I, 585; we are indebted to Niamh Whitfield for drawing these references to our attention; cf. delo duillenda, 'leaf-like brooch', also cited from Táin Bó Cúailgne, RIA Dictionary 'D', 439.62-3.

${ }^{45}$ It perplexed Stokes, op. cit. in note $23,229-30$; perhaps it is a form of the 'suppletive' or substitute verb *to-rola, used for the subjunctive mood and preterite tense of the verb do-cuirethar, the basic meaning of which is 'puts': RIA Dictionary, 'D', $233-8,326.63,364.67-8$.

46 Ó Floinn, op. cit. in note 36, go and examples illustrated in Youngs, op. cit. in note 36, I i I (no. I o6), i I 3 (no. I o8), i I 4 (no. I09), i I 6 (no. I I 2), I 55 (no. I 05) and I 56 (no. I I I); cf. the 'Pictish-style' Kilmainham brooch, ibid., $8 \mathrm{I}$ and $95^{-6}$ (no. 74); cf. Wilson, op. cit. in note $36,7 \mathrm{I}-9,83,98$ and $\mathrm{I}$ o I -2 .
} 
Glossary. The emphasis on falling and top-heaviness, however, seems likely to be a reflex of the distinctive range of motion of the ring and pin of a penannular brooch.

The peculiar form of the catit/cartait, remarked upon in both Cormac's Glossary and O'Davoren's Glossary, may indicate the period in which their glosses originated. By the later 9th/early i oth centuries, when Cormac's Glossary was compiled, types of true penannular brooch were again quite common in Ireland, in the form of the bossed penannular, and the 'ball-type' or 'thistle' brooches. ${ }^{47}$ The origins of the bossed penannular type and the extent to which it was inspired by Scandinavian or Anglo-Saxon metalwork are debated. It has even been proposed that the bossed penannular brooch of the later $9^{\text {th }}$ and ioth centuries owes something to the penannular brooches from 8th- and 9th-century Pictland. ${ }^{48}$ However that may be, a true penannular brooch, with a ring/hoop that has a fastening function, a pin that can turn between the terminals, and the pin-head of which is 'turned back' around the ring/hoop, could no longer be regarded as a Pictish peculiarity by around A.D. 900 (Fig. 3c).

Yet this is how Cormac's Glossary represents it. O'Davoren's Glossary, in also alluding to some distinctive relationship between the pin and ring/hoop of the cartit/cartait, seemingly implies that the Pictish-type penannular is intended, without specifying its Pictish provenance. Barring the unlikely eventuality that the Pictish term for a penannular had become generalised and later could refer even to Hiberno-Viking types of brooch, it seems probable that these glossaries reflect explanations of the catit/cartait that originated earlier than the late gth century. Paul Russell's study of Cormac's Glossary remarks on its compilatory nature, ${ }^{49}$ and the same is surely true of O'Davoren's Glossary. Compilation and recycling of well-rehearsed learning is of the essence of the scholarship involved in the production of Irish medieval glossaries, as has already been pointed out. The arthistorical evidence suggests that Cormac, and doubtless also O'Davoren, drew on pre-existing glosses written in the 8th century or the earlier 9 th, when the broochtype called catit/cartait, and identified as Pictish, differed from the pseudopenannular type favoured in Ireland in the way the pin was attached to the ring/ hoop and in the capacity of the pin to pass between the terminals.

\section{BROOCHES AS CURRENCY AND INDICATORS OF STATUS}

The reference in Bretha Nemed Toisech to brooches as pledges invites some comment on the broader question of brooches as currency and as status-indicators. The association of a brooch as a pledge with the fili, or learned poet, is also found in a story about St Brigit of Kildare, the language of which (late Old Irish or

\footnotetext{
${ }^{47}$ See Youngs, op. cit. in note 36, 89-9o, г oo (no. 82), го3-4 (no. 89) and г o6-7 (no. 93); J. Graham-Campbell, 'Two groups of ninth-century Irish brooches', 7. Royal Soc. Antiq. Ireland, i 02 ( I972), i I 3-28; idem, 'The Vikingage silver hoards of Ireland', 39-74 in B. Almqvist and D. Greene (eds.), Proceedings of the Seventh Viking Congress (Dublin, I 976), 53; idem, 'Some Viking-age penannular brooches from Scotland and the origins of the "thistlebrooch', ', 3 I O-23 in A. O'Connor and D. V. Clarke (eds.), From the Stone Age to the 'Forty-Five (Edinburgh, I 983 ).

${ }^{48}$ Graham-Campbell (I972), op. cit. in note 47, I I6-I7; idem (I983), op. cit. in note 47, 319; P. Michelli, 'Migrating ideas or migrating craftsmen? The case of the bossed penannular brooches', I $82-7$ in R. M. Spearman and J. Higgitt (eds.), The Age of Migrating Ideas (Edinburgh, I993).

49 Russell ( I 988), op. cit. in note I 2, 28; idem (1996), op. cit. in note I 2, I65.
} 
Middle Irish) shows it to be later (perhaps gth- or Ioth-century) than the material discussed above. It mentions:

delg do-rat rí Laigen a ngill do filith

a brooch the king of Leinster gave as pledge to a fili. ${ }^{50}$

Here a pledge comprising a brooch is given to, rather than taken from a fili, but the episode corroborates the use of brooches as a form of currency, for the purposes of exchange and discharging liabilities, among the upper echelons of early Irish society.

Let us explore further the metal composition and the value assigned to the two brooches in Bretha Nemed Toisech, one perhaps of Anglo-Saxon type and the other characteristically Pictish. Each is said to be worth an ounce: together with a drinking vessel worth five ounces, they make up the pledge worth seven ounces of gold that is specified for the ollam. It follows that the value of each brooch is an ounce of gold, not the ounce of silver that is noticed far more frequently as a currency unit in pre-Viking Ireland. ${ }^{51}$ In the case of the brooch designated by the Old English loan-word briar, moreover, we have seen that Cormac's Glossary expressly attributes to it the value of an ounce of gold, while O'Davoren's Glossary may also hint at this. Accordingly, the passage in Bretha Nemed Toisech and the associated glosses must be added to the slim corpus of Irish legal references to gold, noticed variously by Fergus Kelly and Thomas Charles-Edwards. They maintain that an ounce of gold was equated with twelve ounces of silver both in Ireland and elsewhere in Europe around A.D. 700. ${ }^{52}$ Each of the items making up the pledge of an ollam was, therefore, of very high value and the total value of the pledge, at seven ounces of gold or 84 ounces of silver, is remarkably high.

We have discussed the possibility that the epithet derg, 'red', used of the brooch termed a briar, might be a reference to gold as the actual component metal of this type of brooch. Brooches made entirely of gold are not common among surviving artefacts from this period, however. Only two Early-medieval Irish examples have come to light to date: the 9 th-century penannular from Loughan, Co. Londonderry, and a smaller brooch from Kilfinnane, Co. Limerick. ${ }^{53}$ It seems improbable, therefore, though not impossible, that briar denotes a brooch made entirely of gold. Even the fine Anglo-Saxon composite disc brooches to which, it has been postulated above, the term briar might refer, were composed of assorted materials. In some cases, but not all, gold was one of those materials. As regards the Pictish catit/cartait, we may be quite confident that the main metal component was silver,

\footnotetext{
${ }^{50}$ D. Ó hAodha (ed.), Bethu Brigte (Dublin, I 978), xxix-xxx, I 7. I, 34. I and 63; cf. J. Carney, Studies in Irish Literature and History (Dublin, I 955), 53-6.

${ }^{51}$ Kelly, op. cit. in note 7, I I $2-$ I 6 ; idem, op. cit. in note I, 593-5; see also the references cited by C. Etchingham, Viking Raids on Irish Church Settlements in the Ninth Century: A Reconsideration of the Annals (Maynooth, I996), 37n.; O Floinn's suggestion (op. cit. in note 36,72 , following O Corráin), that an earlier, cow-based, currency was 'gradually displaced . . . in the eighth and ninth centuries' by silver may be disregarded.

${ }^{2}$ Kelly, op. cit. in note 7, I I 4, I 64 and I 67; idem, op. cit. in note I, 593-4; T. M. Charles-Edwards, Early Irish and Welsh Kinship (Oxford, i 993$), 482$.

${ }_{53}$ Youngs, op. cit. in note 36, 87 and ro I (no. 83); see Ó Floinn, 'Museum gets gold from Christie's', Archaeology Ireland, 7:3 ( I 993), io (a reference we owe to Niamh Whitfield); for sources of gold in Early-medieval Ireland see N. Whitfield, 'The sources of gold in early Christian Ireland', Archaeology Ireland, 7:4 ( I 993), 2 I-3; eadem, 'Sources of gold in Ireland', Archaeology Ireland, I 2:2 (1998), 40-1.
} 
since silver is the chief constituent of the surviving brooches of Pictish type from the 8th and gth centuries. The heaviest of the Pictish brooches included in the Work of Angels exhibition catalogue is the larger brooch from Rogart, Sutherland, at a little over nine and a half ounces. Others range in weight between just over one ounce and a little over six and a half ounces. ${ }^{54}$ From the above considerations, we would infer that when Bretha Nemed Toisech attributes to each of the two brooches the value of an ounce of gold, this does not indicate either that they were necessarily made of gold, or that the objects themselves each weighed an ounce. It seems a reasonable further inference that the craftsmanship involved in manufacturing the brooches might add greatly to the intrinsic value of the bullion of which they were made. Accordingly, the connection between the value as currency of these brooches and their inherent bullion worth seems not to be the same as that of the silver 'ringmoney', used at a later period in parts of the Insular Viking zone. ${ }^{55}$

If there is limited artefactual evidence for brooches or other objects of gold in this period, their literary profile is more considerable. Old and Middle Irish tales contain a number of references to brooches of gold as worn by aristocratic, heroic or otherworldly characters. ${ }^{56}$ The relationship of such depictions to the material reality of early Ireland is, however, open to debate. Another 8th-century law-text dealing with pledges is more compelling testimony that gold objects were used as a kind of currency among the aristocracy. It is entitled Bretha im Fuillema Gell, 'Judgements concerning Pledge-Interests', ${ }^{57}$ and declares:

ní techta gell n-óir acht ar cenn ríg nó ecalsa nó úasail airechta araili

a pledge of gold is inappropriate except on behalf of a king, a (senior) churchman, or another eminent person of the court. ${ }^{58}$

A later glossator explains that the third category mentioned here includes the fili or learned poet. While our passage of Bretha Nemed Toisech indicates that the pledge proper to an ollam or master of the poetico-learned class might be valued in gold, Bretha im Fuillema Gell and its glossator allow that such a pledge might actually consist of an object or objects made of gold. ${ }^{59}$

A further legal passage is comparatively well known among art historians and others, having been quoted by Françoise Henry (in translation only, from the notoriously untrustworthy igth-century edition of the Ancient Laws of Ireland). The passage refers to the brooches properly worn by the sons of various grades of king while they are in fosterage:

${ }^{54}$ Youngs, op. cit. in note 36, I I $0^{-}$- 6 .

${ }^{55}$ B. Crawford, Scandinavian Scotland (Leicester, I987), I33-4; Graham-Campbell, 'The northern hoards of Viking-age Scotland', I 73-86 in C. E. Batey et al. (ed.), The Viking Age in Caithness, Orkney and the North Atlantic (Glasgow, I 993); S. E. Kruse, 'Silver storage and circulation in Viking-age Scotland', ibid., I 87-203; J. GrahamCampbell and C. Batey, Vikings in Scotland: An Archaeological Survey (Edinburgh, I998), 62, 63, 65, 69-70, 76, 78-9, $23 \mathrm{I}, 235,237-9$ and $243-6$.

56 A. G. Van Hamel (ed.), Compert Con Culainn and Other Stories (Dublin, I 933), 25 § I 5 (éo óir); Myles Dillon (ed.), Serglige Con Culainn (Dublin, i 953), i 8.508 (delg óir); J. G. Watson (ed.), Mesca Ulad (Dublin, i 94 I), 28.533 (mílech óir); T. P. Cross and C. H. Slover (ed.), Ancient Irish Tales (New York, I 936), I 56, i 89 and 226; Mallory, op. cit. in note 44, I $43^{-6 .}$

${ }_{57}$ Binchy, op. cit. in note, 9, 462.19-477.30 (see Kelly, op. cit. in note 7, 278); L. Breatnach, 'On the original extent of the Senchas Már', Eriu, 47 ( I 996), I-43 at p. 27.

58 Binchy, op. cit. in note $9,467.34^{-5}$, with length-marks supplied; the translation is our own.

${ }^{59}$ Binchy, op. cit. in note 9, 468.2; Kelly's interpretation of úasal airechta araile as 'lord' (op. cit. in note 7, I64), may require slight modification in the light of the gloss. 
ocus deilge óir ocus glaini do beth indte ac macuibh rígh Érenn ocus rígh cóicidh, ocus delge airget do macuibh rígh túaithe ocus mórthúaithe; nó comu inund dealg do mac cach ríg ocus in eacor-sin uile isin dealg-sin

and sons of the king of Ireland and of the king of a province should have gold brooches with crystal/glass on them; silver brooches for the sons of the king of a single community and of a greater community; or a similar brooch for the sons of every (grade of) king, with the full decoration on that brooch. ${ }^{60}$

With reference to this, Henry declared that 'the wearing of brooches as insignia of rank and social position is mentioned in the collection of laws, the Senchas mór' ${ }^{61}$ In point of fact the relevant passage belongs not to the 8th-century Senchas Már itself, but to the accompanying Middle Irish commentary, probably of I Ith- or I 2 th-century date. Accordingly, while potentially illuminating about brooch-types and their social significance in the latter era, this text, on the face of it, is not good evidence for the pre-Viking period discussed here.

We have already seen that the 8th-century law-text Bretha im Fuillema Gell restricts use of a pledge of gold to persons of the highest social status, such as a king, a senior cleric or a fili. Granted this restriction, however, precious metal objects for use as pledges were apparently of rather wider social distribution than one might, perhaps, expect. That, at any rate, is the implication of another passage of 8thcentury law, also in Bretha im Fuillema Gell. The specific topic dealt with in this as yet untranslated law-text is pledge-interest, that is to say, the return one might earn by lodging a pledge on behalf of a third party. The text treats at one point of the pledge-interest appropriate to an aicde argait, 'manufactured object of silver', exemplified, in the view of a later glossator, by dealg nó fail, 'a brooch or (arm-) ring'. As elsewhere in this law-text, the interest due on such a silver artefact relates to the status of the person lodging the pledge. There is, accordingly, reference to the substantial pledge-interest due on a silver artefact owned by a king or a masterfili. Smaller pledge-interests are prescribed in the case of silver artefacts owned by lesser nobility. Surprisingly, perhaps, it is also envisaged that such a silver artefact might be pledged by a bóaire and even by a ócaire, these being, respectively, the higher and lower grades of 'commoner' known to the early Irish social system. These two have been likened to the 'strong farmer' and 'small farmer' of 2othcentury Ireland. Whatever be the relevance of such analogies, it would appear that both might enjoy ownership of luxury items, including silver artefacts, possibly brooches ${ }^{62}$ It is well known that the 8th-century law-text on status entitled Crith Gablach numbers among the expected possessions of the aire désa, the lowest grade of nobility, a clothdelg n-ungae, 'precious brooch worth an ounce' (here presumably the regular ounce of silver).$^{63}$ If the glossator of Bretha im Fuillema Gell can be relied

\footnotetext{
${ }^{60}$ Binchy, op. cit. in note 9, I 759.2 I-4, with length-marks and punctuation supplied; the translation is our own

${ }^{61}$ Henry, Irish Art in the Early Christian Period, to A.D. 800 (rev. ed., London, I 965), I 02; Henry's citation of the Ancient Laws of Ireland and her misapprehension with regard to the date and nature of the text is followed inter alios by M. R. Nieke, 'Penannular and related brooches: secular ornament or symbol in action?', i $28-34$ in Spearman and Higgitt (eds.), op. cit. in note 48, I 28.

${ }^{62}$ Binchy, op. cit. in note 9, 468.7-27; on the bóaire and ócaire see conveniently Kelly, op. cit. in note 7, Io.

${ }^{63}$ D. A. Binchy, Crith Gablach (Dublin, I 94I), I 4.346; see Kelly, op. cit. in note 7, I I 4, and cf. Nieke, op. cit. in note 6 I, I 29 .
} 
upon, then the most substantial non-noble classes might also own silver brooches in pre-Viking Ireland. Should they be envisaged, perhaps, as akin to gentry in status? Consideration of this legal evidence may thus significantly modify the picture, deduced especially from the Ulster cycle of tales, of precious-metal brooches as peculiarly aristocratic status-markers. ${ }^{64}$

\section{GONGLUSION}

All the indications are that the two brooches associated with the master-fili as objects suitable for pledging, in Bretha Nemed Toisech and associated glosses, were of an exceptional order as regards rarity and value. Further elucidation of what precisely was the briar must be left to experts in elite metalwork. The catit/cartait was, as far as we can tell, none other than the Pictish penannular brooch. Why would an accomplished Irish fili or scholar-poet of the 8th century, perhaps located in the southern province of Munster (on the basis of the suggested provenance of Bretha Nemed Toisech), possess such objects? The obvious route to enrichment for a fili was patronage and payment of a dúas filed, 'fili's reward', for commissioned composition. There is at least one reference in a Middle Irish text (i.e. post-gthcentury) - a short hagiographical anecdote, the subject of which is, again, St Brigit - to a silver brooch given to a fili by the king $i$ llóig a dána 'as reward for (the exercise of) his talent'. ${ }^{65}$ One is tempted to conjecture, in view of the range of patronage commanded by the admittedly later medieval bardic poets of Ireland and Scotland, that the catit/cartait might be earned as 'fili's reward' in Pictland. Given their contact with Dál Ríata, some at least of the 8th-century Pictish nobility must have been functionally bilingual and may have patronised Gaelic literati, as we know the Gaelic-Norse potentates of later times did. ${ }^{66}$ Might similar opportunities for Gaelic literati have existed in Northumbria, at least during the 7 th century? This is, of course, no more than speculation. What one can say is that a small number of Pictish or Pictish-style penannular brooches of 8th- or earlier 9thcentury date have turned up in Ireland. An example of the former is the Ballynaglogh brooch from Co. Antrim. An example of the latter is the remarkable Kilmainham, Co. Dublin, brooch, which is clearly influenced by the Pictish model, yet appears in its detail to be an Irish product. Both are well illustrated in the Work of Angels catalogue (Fig. 4). ${ }^{67}$

To sum up, a passage of the 8th-century law-text Bretha Nemed Toisech and glosses expounding its brooch-terminology suggest contemporary recognition alike of Anglo-Saxon, Pictish and Irish traditions of elite metalwork craftsmanship. The

\footnotetext{
${ }^{64}$ Mallory, op. cit. in note 2, $5 \mathrm{I}-2$; cf. Nieke, op. cit. in note $6 \mathrm{I}$.

${ }^{65}$ W. Stokes and J. Strachan (eds.), Thesaurus Palaeohibernicus, 2 vols. (Cambridge, I 903), ii, xxxv-xxxvi and 345 ; it is presumably to this episode that O Floinn refers, op. cit. in note 36, 72; on the dúas filed see Kelly, op. cit. in note $7,45^{-8}$

66 For Viking leaders as subjects of Gaelic praise poetry see B. Ó Cuív, 'Personal names as an indicator of relations between native Irish and settlers in the Viking period', 79-88 in J. Bradley (ed.), Settlement and Society in Medieval Ireland: Studies Presented to F. X. Martin, O. S. A. (Kilkenny, I988), 87 n. I9; idem, 'A poem in praise of Raghnall king of Man', Éigse, 8 ( I $955 / 57$ ), 283-30 I.

${ }_{67}$ Youngs, op. cit. in note 36,8 I, 95-6 (no. 74), 86 and Io2 (no. 85); cf. Wilson, op. cit. in note 36, 83-4, 90, 93, $94^{-5}$ and 102 .
} 


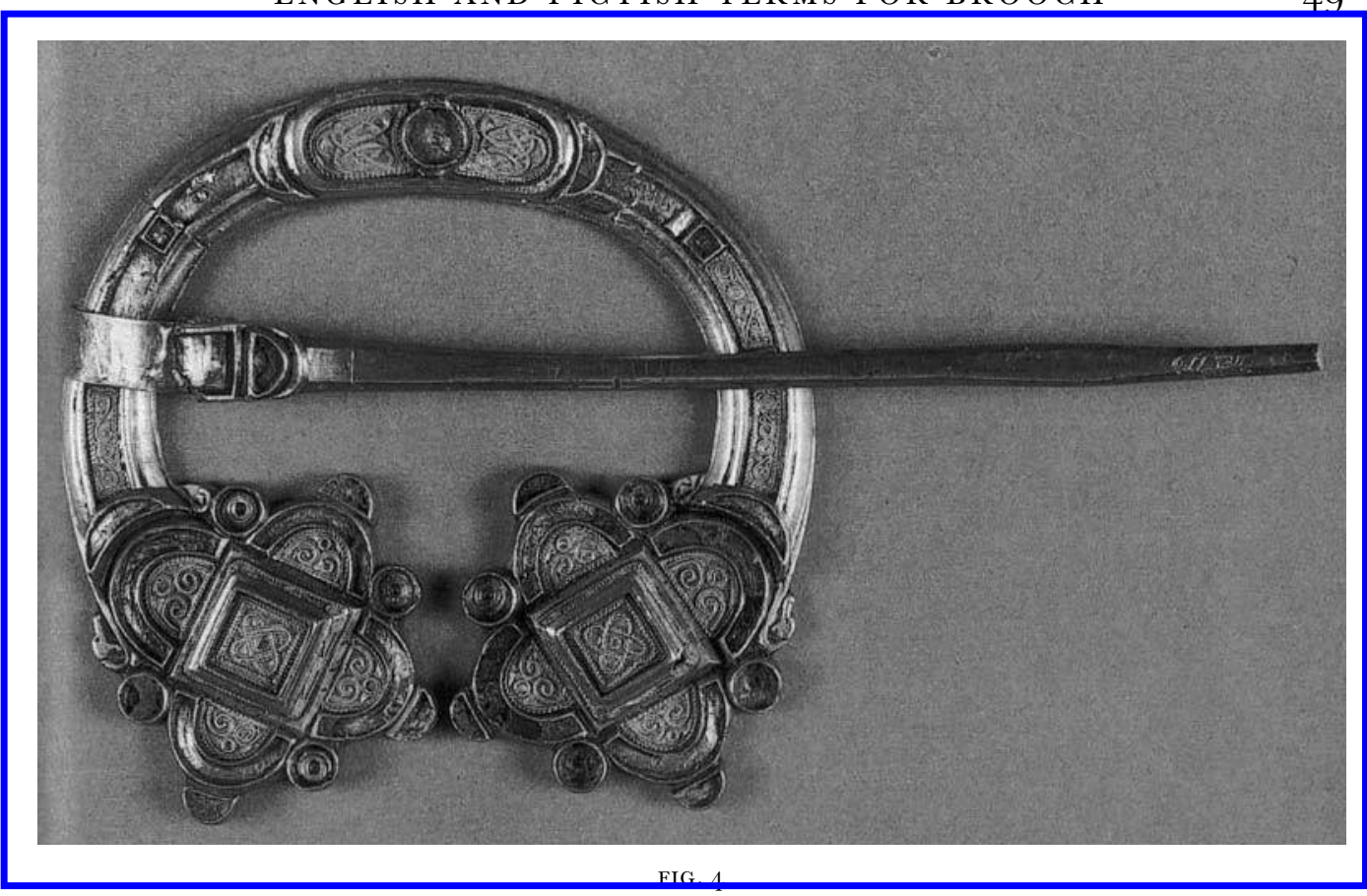

The hybrid brooch from Kilmainham, Co. Dublin. Scale r: I.

texts may allude to an identifiably Anglo-Saxon brooch-type, though satisfactory evaluation of this hypothesis must await the response of art-historians. The documentation plainly shows an awareness of the distinctive form and technical function of the Pictish penannular brooch, designated by a word of the Pictish language, itself a treasure of great rarity value. It is hoped that this paper will serve to show the potential of hitherto largely hidden texts to cast light on some of the material realities of the Early Middle Ages, with which archaeologists and art historians are concerned.

\section{AGKNOWLEDGEMENTS}

We wish to record our debt to Niamh Whitfield, without whose assistance and encouragement this paper would not have been written. 